\title{
CONFLUÊNCIAS POLÍTICAS DA PEQUENA BURGUESIA: O ANTIPETISMO DE DIREITA E DE ESQUERDA
}

Cesar Mangolin*

Resumo: $\mathrm{O}$ artigo pretende contribuir com a análise do processo que culminou no golpe que derrubou o governo da presidenta Dilma Rousseff e na sua caracterização de classe e, particularmente, expor em linhas gerais duas expressões políticas da ideologia pequeno burguesa que estiveram na base do apoio ao golpe, uma do campo da direita e outra do campo da esquerda.

Palavras-chave: Direita, Esquerdismo, Golpe de Estado.

Abstract: The article intends to contribute with the analysis of the process that culminated in the coup that overthrew the government of the president Dilma Rousseff and in its characterization of class and, in particular, to expose broadly two political expressions of the petty bourgeois ideology that were the basis of the support to the coup, One from the right field and one from the left field.

Keywords: Right, Leftism, Coup d'etat.

\section{Introdução}

Muitos artigos e já alguns livros têm surgido analisando a composição de classe do golpe e muitos ainda aparecerão por décadas, e nosso artigo não pretende, obviamente, fazer a análise de todos os seus aspectos. Nossa intenção é, primeiro, esboçar uma caracterização geral do golpe em andamento e, depois, tratar do papel político dos setores médios ou da pequena burguesia ${ }^{1}$, que se distinguirá ideologicamente em duas posições opostas em alguns pontos e confluentes em outros tantos: a primeira, aquela da nova militância e de

\footnotetext{
* Doutor em Filosofia (Unicamp), professor da Universidade Metropolitana de Santos (UNIMES).

${ }^{1}$ Optamos por não poluir o texto com citações diversas exatamente para procurar dar conta da dinâmica histórica recente. Mas deixamos explícito nosso referencial sobre a definição de pequena burguesia nos sentidos político e econômico e suas disposições ideológicas: para o aprofundamento conceitual, ver nas referências bibliográficas as obras de Poulantzas, (1968 e 1972).
} 
organizações da direita; a segunda, a militância e as organizações esquerdistas, no sentido pejorativo do termo, como foi atribuído por Lênin em seu célebre $A$ doença infantil do “esquerdismo" no comunismo (1980).

Pensar criticamente as características opostas e ao mesmo tempo confluentes dessas duas posições políticas da nossa conjuntura não elimina, obviamente, todas as possibilidades de análise do papel da pequena burguesia e suas camadas no processo do golpe que, aliás, é um trabalho teórico que precisa ser feito com a devida profundidade. Para que fique bastante claro e bem recortado, nosso objeto de análise são os movimentos, agrupamentos e partidos do campo político da direita e da esquerda, que foram levados à unidade por suas disposições diante dos governos petistas (mais propriamente, do ciclo de governos do PT e não apenas dos mandatos da presidenta Dilma Rousseff), que denominamos como um antipetismo de direita e um antipetismo de esquerda.

Para tanto, dividimos nosso artigo em duas partes, seguidas de rápidas considerações finais: na primeira parte, ensaiaremos uma rápida caracterização geral do golpe e de seu caráter de classe; depois, na segunda parte, pensaremos nos argumentos que nos permitem tratar grupos aparentemente (e em alguns aspectos de fato) antagônicos como uma unidade para, por fim, tratarmos das características do antipetismo de direita e do de esquerda.

\section{O golpe e seu caráter de classe}

O segundo mandato da presidenta Dilma Rousseff, conquistado por votação direta em 2014, foi interrompido por um golpe em 2016.

Compreender a composição das forças políticas que se articularam a favor e contra o golpe e, de outro lado, os limites das forças políticas que pretenderam impedir o golpe e que ainda se batem contra ele é um trabalho teórico imprescindível para que haja a correta compreensão do processo, da sua dinâmica e das suas contradições. Podemos afirmar que o golpe ainda está em curso e que há contradições no interior das forças golpistas que disputam seus resultados. Tal análise depende sempre da identificação das classes e frações de classe em luta e da capacidade de cada fração, na luta por seus interesses específicos, de estabelecer alianças pontuais ou mais duradouras com outras frações.

No caso em questão, sabemos da confluência de interesses no sentido do golpe de frações do grande capital financeiro, das corporações petrolíferas internacionais, do imperialismo estadunidense (incomodado pela política externa brasileira e pela participação 
do país no BRICS), das grandes empresas da comunicação e de uma parte considerável de partidos e políticos brasileiros que, de um lado, utilizou do expediente golpista para bloquear um ciclo de governos e um projeto que não foi derrotado nas urnas, portanto, pelas vias legais e, de outro lado, bloqueou um ciclo de governos que ameaçava constantemente os interesses de uma política fisiológica e secularmente antipopular. Estão presentes neste parágrafo, portanto, duas compreensões fundamentais do processo que nos servem de base para qualquer análise, que podemos sintetizar da seguinte maneira: 1) a derrubada da presidenta Dilma Rousseff foi um golpe e um atentado perigoso à nossa frágil democracia, ainda que limitada pela ordem burguesa; 2) o governo foi derrubado por seus méritos, não por seus problemas objetivos e muito menos por aqueles forjados pela sanha golpista midiática e de toga.

Mas ainda há mais um elemento necessário da análise. Identificar as classes e frações de classes que, por interesses diversos, se reúnem numa unidade para organizar e desfechar o golpe exige ainda pensar na sua base social, forjada por disposições político-ideológicas oriundas do seu lugar nas relações sociais e mobilizada pelas intensas campanhas da TV, revistas e jornais. Por base social compreendemos aqueles setores que se dispuseram a encarar a tarefa do golpe como uma causa que possuía um sentido mais ou menos claro, ainda que resultado das deformações e deturpações de toda ordem. Setores da população brasileira (para usar ainda um termo genérico, mas aproximativo) que não possuem interesses diretos no processo de golpe, como as vantagens econômicas das frações da classe burguesa, preteridas no ciclo de governos do PT em favor de uma burguesia interna, ligada à construção civil e pesada, que é punida com a prisão após o golpe (cf. Boito, 2016). Ora, se afirmamos que há setores dispostos à luta contra o governo federal que não se beneficiam diretamente e não se movimentam conscientemente por ter como causa seus interesses econômicos, estamos dizendo que a análise somente pode ser completa caso pensemos nas disposições ideológicas que tornam parte da população a base social ou a massa própria de manobra para que aqueles interesses difusos de frações de classes distintas se realizem através do golpe. Falamos particularmente nesse caso da pequena burguesia, ou dos setores médios, ou ainda, classe média, como alguns preferem.

\section{A pequena burguesia e a oposição ao governo Dilma}




\subsection{A unidade dos contrários}

$\mathrm{O}$ que permite pensar uma unidade, ainda que manifestamente esses grupos sejam contrários em termos de princípios e objetivos estratégicos? Lembremos que temos nos dois extremos posições de grupos que se assumem neonazistas e, de outro lado, a autointitulada esquerda revolucionária, dispersa em pequenos partidos, coletivos, etc.. A unidade de grupos aparentemente tão distintos pode ser verificada em pelo menos dois aspectos: primeiro, a oposição radical e a avaliação negativa do ciclo de governos do PT; segundo, explicações similares sobre o golpe presentes nas duas posições, quais sejam: a) o governo caiu porque é corrupto; b) o governo caiu porque fez alianças com a direita ou com a esquerda; c) Michel Temer foi o vice-presidente eleito na chapa do PT, portanto, a "culpa" é do PT mesmo e seus aliados, mesmo os do campo da esquerda, como o PCdoB.

Um rápido e sumário comentário sobre cada uma dessas posições é necessário para tentar demonstrar como são explicações presentes nos dois grupos e, ao mesmo tempo, falaciosas ou que não correspondem plenamente à realidade objetiva.

\subsection{1.“O governo caiu porque era corrupto!”}

A primeira posição é mais frouxa, como bem sabemos, embora seja recorrente e importante principalmente para a pirotecnia midiática. Não porque a corrupção não seja um problema (inclusive um problema teórico que deve ser corretamente tratado, como podemos ver em Boito, 2017), mas porque foi apenas o pretexto e jamais a questão central em todo o processo. Quanto mais nos distanciamos no tempo do momento da queda da presidenta eleita e da ascensão do governo golpista e ilegítimo de Michel Temer, ficam mais claras as disposições pessoais e da sua camarilha de estancarem as possibilidades de investigações que os atingissem, como foi de maneira clara e direta expresso na gravação telefônica do Senador Romero Jucá, do $\mathrm{PMDB}^{2}$. Mas há outro aspecto notável no discurso moralista sobre a corrupção e que demonstra bem sua utilização para fins apenas políticos e para os objetivos do golpe: não há disposição alguma para a apuração das denúncias envolvendo quaisquer personagens que não estejam ligados aos governos petistas, ainda que apareçam evidências materiais e isso ocorre entre as referidas disposições e no próprio poder judiciário. A

\footnotetext{
${ }^{2}$ Aos que não se lembram, Romero Jucá diz ao seu colega que era necessário derrubar a presidenta Dilma Rousseff como condição única para que se estancassem os processos de investigação da corrupção.
} 
tendência de utilização de um ou outro caso exemplar ocorre (como o caso de Aécio Neves) e ocorrerá apenas na medida em que for necessário para justificar e embasar medidas mais drásticas com relação àqueles ligados aos governos petistas e, em particular, para justificar uma ação que neutralize o ex-presidente Lula, seja num amontoado de processos exaustivamente divulgados para associar sua imagem à corrupção, seja através da prisão.

2.1.2. As alianças do governo: direita ou esquerda?

Ainda que em campos opostos, o argumento aparece tanto a partir dos militantes e agrupamentos de direita, quanto os de esquerda.

Os grupos de direita irão reproduzir histericamente a ideia um grande complô da esquerda, à semelhança daquelas peças de propaganda baseadas em fantasiosas teorias da conspiração dos tempos da Guerra Fria. Para esses grupos, tudo e quase todos são de esquerda e pretendem tornar o Brasil algo como a Venezuela ou Cuba e, não é necessário insistir, eles possuem poucas de deturpadas informações sobre esses países. Um bom exemplo e de ampla divulgação foi a mulher que identificava, no Congresso Nacional, o vermelho da bandeira japonesa como a prova da dominação cultural dos comunistas.

Mas atribuir os problemas e a queda do governo Dilma à sua composição política também aparece no discurso das organizações de esquerda. Claro que temos nesse campo abordagens um tanto quanto mais sérias ou, pelo menos, mais comedidas e, inclusive, há elementos da crítica à conciliação de classes que devem ser levados em consideração e refletidos, principalmente quando pensamos em momentos de altos índices de aprovação dos governos de Lula. Mas afirmar insistentemente que o problema do ciclo de governos do PT foi o arco de alianças e a conciliação de classes pode bem satisfazer aqueles que estão acostumados a ficar pelo meio do caminho ou estão mal intencionados e apenas adicionando elementos aos seus discursos apenas moralistas, deixando sem explicação, objetivamente, a pergunta que deve ser feita: por qual razão ocorreu ou foi necessário esse arco de alianças e não outro? Ora, as alianças são estabelecidas ao gosto das forças políticas ou é a conjuntura que abre um determinado leque de possibilidades e opções, diante das quais devem tomar decisões?

Nossa posição é que a conjuntura de crise das políticas neoliberais do final da década de 1990 e começo dos 2000 possibilitou governos progressistas, de esquerda e centroesquerda, por toda a América Latina e também na Europa. Mas essa possibilidade aberta pela 
crise econômica foi contingenciada pelas conjunturas internas de cada país, ou seja, as possibilidades dessas experiências serem mais ou menos avançadas dependeram, como sempre, do nível de acirramento das lutas de classe dentro de cada país. Isso, sem dúvida, explica a capacidade de tomar medidas mais ou menos progressistas por esses novos governos, mas antes disso e fundamentalmente explica o caminho para a chegada ao governo de forças políticas progressistas e o espaço real de autonomia relativa: as experiências mais amparadas em movimentos populares mobilizados e com histórico recente de grandes lutas nacionais pode explicar, por exemplo, a maior radicalidade das experiências da Bolívia, do Equador e da Venezuela, assim como o menor acirramento interno das lutas de classe pode explicar a necessidade de atribuir maior peso ao processo institucional e buscar alianças para além do campo popular e de esquerda para viabilizar vitórias eleitorais. Isso não ocorreu somente no Brasil, mas também na Argentina, no Chile, no Paraguai, no Uruguai, na Nicarágua, etc. Após um breve ciclo de crescimento econômico, mas, principalmente, de desenvolvimento social, algumas dessas experiências (as mais e as menos avançadas) passaram a sofrer reveses com a persistência da crise internacional do sistema capitalista associada às condições políticas internas. Esses reveses ocorreram por via eleitoral e por via de golpes, após processos de desestabilização política, mais que de crise econômica. Exemplos de viradas eleitorais são os casos do Chile - que retomou depois com a nova eleição de Bachelet -, da Argentina e a eleição de Macri com um programa neoliberal, de vários países da Europa e da ascensão de partidos e candidatos associados diretamente a posições desde o centro até a extrema direita. Noutros casos, diante da impossibilidade ou incapacidade de vitória eleitoral dos setores reacionários, o caminho foi o golpe, como ocorreu em Honduras, no Paraguai, no Brasil e está em curso na Venezuela.

A sempre recordada Carta aos Brasileiros, de Lula e do PT, na campanha de 2002, materializava a opção feita entre a possibilidade de ganhar as eleições fazendo concessões ou perder novamente as eleições, mantendo princípios que no caso do PT não estavam muito distantes daquilo que concedia. Para deixar mais claro o que pretendo afirmar: a trajetória política do PT ao longo de duas décadas pode ser compreendida como o processo em que sua linha política e seu programa se ajustam coerentemente ao seu perfil socialdemocrata, o que não torna a referida Carta aos Brasileiros apenas um amontoado de concessões, mas também um esclarecimento. Somente quem tinha ou tem ilusões com supostas disposições revolucionárias do PT é capaz de compreender a Carta e o programa dos governos do partido como sendo uma concessão ou uma traição a princípios. E, mesmo assim, estamos diante do ciclo de governos mais progressistas que tivemos na história brasileira. Foi necessária a 
ampla e heterogênea frente de partidos e movimentos populares que tornou possível a eleição de Lula, cuja vice-presidência era ocupada por um empresário do extinto Partido Liberal. A composição do governo refletiu essa frente, sem dúvida. Mas provavelmente não haveria a vitória eleitoral não fosse essa montagem, assim como não ocorreria nas eleições sucessivas.

Há dois pontos importantes ainda aqui: um se refere a algo que não ocorreu na relação entre governo e os movimentos populares. Outro, que ocorreu e tem relação com as condições de vida de trabalhadores mais empobrecidos e dos setores médios e é desprezado pura e simplesmente pela maior parte dos grupos à direita e à esquerda.

No primeiro caso, não é raro ouvir que a sequência de governos (os dois de Lula e o de Dilma) poderia ter criado bases sociais para saídas mais avançadas, ou seja, estimulado os movimentos populares a assumirem um protagonismo maior nas lutas políticas. Mas tal perspectiva apenas revela duas coisas: de um lado, a incapacidade dessas organizações perceberem que a experiência do ciclo petista era a do Estado burguês e não de uma estrutura jurídico-política de transição socialista. Aliás, o PT jamais deu a entender a menor possibilidade de ocorrer o contrário. Há aí, sem dúvida, uma compreensão ingênua do processo histórico e uma visão paternalista e ilusória com relação ao Estado burguês, que em casos similares tende sempre a cooptar movimentos e lideranças populares; de outro lado, essa lamúria em forma de crítica apenas revela as dificuldades próprias do trabalho de organização política de base de partidos e organizações consequentes do campo da esquerda e a incapacidade dos partidos e movimentos esquerdistas de sequer dialogar com setores de fora do universo pequeno-burguês. A inserção dos movimentos populares e a capacidade de formação de trabalho de base são fundamentais para que qualquer possibilidade mais progressista possa ocorrer. É da capacidade de luta, de mobilização e de organização dos trabalhadores que depende qualquer saída mais avançada e até revolucionária, não da máquina do Estado burguês.

No segundo caso, tanto organizações esquerdistas quanto as da nova direita vão tratar os governos com o perfil do ciclo petista como se não fossem fundamentais para conquistas dos trabalhadores de condições e "direitos" que secularmente lhes foram negados. Ainda que imbricados nas contradições e necessidades de ceder ao grande capital e, ao mesmo tempo, realizar avanços sociais, ninguém pode negar que as condições de vida dos trabalhadores por todo o país foram elevadas positivamente e que jamais se fez tanto pela redução ou eliminação da miséria e das desigualdades sociais gritantes. Esses dados positivos para trabalhadores, envolvendo também os setores médios, tornam esse ciclo de governos mais que apenas um amontoado de erros como querem fazer crer, à direita e à esquerda, os 
referidos grupos. Somente aqueles que estão inseridos ideologicamente no individualismo radical pequeno burguês raciocinam assim.

\subsection{3. "A culpa é do PT”: a posição de Michel Temer e do PMDB}

Michel Temer, um político tradicional do centro pantanoso que é o PMDB, que tende para qualquer lado onde possa ocupar mais espaço, era parte de um governo com esse perfil mencionado acima: que foi eleito por uma frente heterogênea de partidos, mas com compromissos sociais claros, com os trabalhadores e com determinadas frações do capital que eram atendidas prioritariamente nos seus interesses porque faziam parte do projeto neodesenvolvimentista que estava na base desse governo e era seu programa.

As demais frações do grande capital participavam, sem dúvida, secundariamente. É necessário compreender as contradições internas da própria burguesia, porque é uma parte dela e não seu conjunto quem está por detrás do golpe. Não se deve esquecer que uma parcela da burguesia está, inclusive, na cadeia: as grandes empresas responsáveis pela construção pesada, pela construção civil, pela indústria naval, de segurança territorial, etc. Aliás, exatamente aquela fração privilegiada pelo programa desse ciclo de governos (ver Boito, 2016).

Michel Temer não foi eleito para fazer parte de um golpe de Estado: foi eleito dentro das regras democráticas e da ordem constitucional para ser o vice-presidente de um governo que tinha programa já aplicado e em andamento. Reduzir o golpe a questões pessoais, a busca de culpados ou personalizar o golpe como uma armação de Temer e uma vingança de Eduardo Cunha é reduzir o problema a uma intriga palaciana e perder sua dimensão política e de classe - dimensão política e de classe que começou a mostrar bem seus contornos desde as manifestações de junho de 2013, que foram tomadas pela pequena burguesia por todo o país, contando, curiosamente, nas suas grandes manifestações com os novos e velhos militantes da direita e também com as organizações esquerdistas, que tinham seus símbolos e bandeiras rasgados, militantes agredidos, etc. Ficava claro que havia uma articulação diferente da direita em andamento e que havia a ameaça de golpe.

Com o início do processo eleitoral em 2014 ficou bastante evidente que não teríamos uma eleição qualquer: tínhamos dois projetos de dentro da ordem burguesa, sem dúvida, mas dois projetos em disputa, sendo que o que vinha da direita ganhava força, o que fícou expresso na campanha (mais violenta que de costume) e na votação final. Era necessário a 
partir dali defender o governo de Dilma, mesmo para os que faziam uma crítica do ciclo petista pela esquerda. Era necessário não porque o caminho era a posição política do "governismo acrítico", mas porque estava claro que o que viria em seu lugar significaria um forte retrocesso. Parece que passado pouco mais de um ano da consumação do golpe temos dados suficientes que comprovam isso empiricamente.

Mas pelas características dos grupos que denominamos aqui de antipetistas de direita e de esquerda, esse raciocínio simples e óbvio aparecia, para os primeiros, como uma conspiração política de petralhas esquerdopatas que destruíram o Brasil e, para os segundos, como posições de conciliadores de classe e renegados da revolução. Nessas posições distintas, ambos os lados deram os braços e operaram, com pesos políticos distintos, em favor da derrubada da presidenta Dilma Rousseff e do golpe.

\subsection{O antipetismo de direita e de esquerda}

\subsection{1. “A culpa é da Dilma!” - O antipetismo de direita}

Os neomilitantes de direita tomaram problemas seculares do Brasil como se fossem obras dos governos do PT e até atribuíram à presidência da República responsabilidades de outras instâncias, como ocorreu com a falta de água em São Paulo e os problemas com a segurança pública. O bordão "a culpa é da Dilma" se tornou a chave para expor todo tipo de preconceito e dar vazão a discursos violentos contra os mais vulneráveis socialmente. Há um nível muito alto de agressividade entre esses militantes, o que torna a tentativa de argumentar e tratar desses temas um esforço quase inútil.

A movimentação da grande mídia, de partidos e políticos tradicionais com "capivaras" imensas, do judiciário e de uma massa de manobra histérica pareceu ser a de gente que só recentemente começou a viver e perceber as mazelas do tipo de capitalismo que se desenvolveu no Brasil. Embora falem em nome de algum Brasil, fica claro pelo que defendem que não incluem o Brasil da população que mais sofreu, pela marginalização e empobrecimento contínuos, com a dragagem das nossas riquezas naturais e com a concentração da riqueza gritante e secular.

Essa massa de manobra essencialmente pequeno burguesa não faz parte, obviamente, da seleta elite que concentra em suas mãos o grosso da riqueza social produzida. Mas seus militantes de direita repetiram chavões e palavras de ordem sem sentido e serviram de base 
para a crise política que interessava apenas a determinados setores do grande capital. Foram e são apenas marionetes dele. Como disse João Quartim de Moraes, "É evidente que os empreiteiros do golpe só prosperaram porque conseguiram manipular com êxito frustrações, ressentimentos e ódios do reacionarismo latente nos setores mais obscurantistas e empedernidos da pequena burguesia (ou "classe média", como dizem muitos)" (Moraes, 2016).

Os governos do PT atenderam, sem dúvida, prioritariamente aos interesses de uma fração do grande capital, afinal, foram governos dentro da ordem burguesa que dirigiram o Estado capitalista. Mas ao deslocarem esforços e recursos no atendimento a populações deixadas de lado por nosso processo histórico, deslocaram recursos dos cofres do grande capital que sempre tem espaços vazios para serem ocupados. A separação de dinheiro público e privado, assim como, em última instância, as noções de público e privado são, sem exceções, apenas definições jurídicas e não parece ser necessário lembrar que a estrutura jurídico-política não existe em separado da estrutura econômica e da estrutura ideológica, servindo, portanto, para a reprodução das relações capitalistas de produção. (Sobre uma discussão teórica mais aprofundada sobre o tema da corrupção ver Boito, 2017).

Mas os que apoiaram o golpe pela direita não sofreram apenas de uma dificuldade de compreensão da realidade: esses limites estão postos também para boa parte dos que lutaram contra o golpe. Em síntese, o antipetista de direita sabia que o processo não tinha nenhuma relação com a luta contra a corrupção. Ele saiu às ruas com a camisa da $\mathrm{CBF}$, tirou fotos com a polícia sorridente, gritou "somos todos Cunha" e dançou em volta do pato da Fiesp. O golpista apoiou a perseguição a lideranças do PT porque eram do PT, porque odeiam qualquer coisa que cheire a trabalhador, ainda que eles mesmos sejam, no geral, trabalhadores. Odeiam a melhoria das condições de vida dos mais pobres porque isso lhes ameaça os canais tradicionais de manutenção como pequena burguesia; mas odeiam também porque perdem aquela parcela da população que pode lhes servir em troca de um prato de comida ou de qualquer punhado de moedas, como bem mostrou a reação das "madames" quando direitos trabalhistas básicos passaram a vigorar para o trabalho doméstico.

O problema é que a pequena burguesia possui um sonho e um medo: o sonho é do aburguesamento individual; o medo é o da proletarização. Tudo o que ocorre para esse insano grupo de pessoas é creditado apenas e tão somente como produto do seu mérito pessoal, não podendo reconhecer, portanto, que as mudanças que ocorreram nos últimos anos no Brasil melhoraram também sua vida. Mas o sonho de ser burguês e o medo de se proletarizar envolvem o que é individual e o que é coletivo: enriquecer deve ser algo individual, porque 
os ideais de sucesso gestados na ordem capitalista não passam apenas pela aquisição de bens materiais, mas necessariamente por algum grau de distinção, para que a riqueza seja ostentada e reconhecida. A proletarização é coletiva e nesse caso não significa empobrecimento. Para a pequena burguesia, o acesso de camadas empobrecidas da população a condições mais razoáveis de vida, o acesso a espaços que lhes foram sempre bloqueados, a determinadas carreiras, determinados serviços, enfim, a proximidade dos "pobres" que já não vão aparecer tão pobres assim joga areia no seu projeto individual, amplia a concorrência, faz com que se percam os canais tradicionais de sua manutenção e justificação em determinados postos e carreiras (particularmente aqueles justificados pela certificação escolar).

Por isso que no momento em que sentiram os primeiros efeitos da crise econômica batendo em suas portas reagiram com tanta raiva aos programas sociais, com tanta raiva contra as cotas sociais, com tanta raiva contra governos como os do ciclo petista, sendo facilmente arregimentados por partidos e organizações de direita, ainda que os interesses da pequena burguesia e os do grande capital não sejam coincidentes.

\subsection{2. "Viuvez ou adultério?" O antipetismo de esquerda}

Dilma concorreu nas eleições de 2014 com outros dez candidatos. Seis deles eram expetistas: Eduardo Jorge (PV), Marina Silva (PSB), Luciana Genro (PSOL), José Maria (PSTU), Mauro Iasi (PCB) e Rui Costa Pimenta (PCO). Nenhum deles apoiou o PT no segundo turno.

Os dois primeiros já estavam no colo da direita e se juntaram ao PSDB. O PSOL, que teve o mérito de pelo menos perceber as contradições do processo, liberou a militância para o voto, desde que não fosse em Aécio (PSDB), restando, portanto, o voto em Dilma ou a anulação, voto em branco ou abstenção. Os dois partidos trotskistas e o PCB declararam o voto nulo.

Claro que há razões apenas políticas (ainda que equivocadas) para a tomada de posição desses partidos, mas como não pensar que a coincidência dos ex-petistas não agrega ao jogo uma pitada de questões subjetivas?

Nossa posição aqui reflete dois problemas distintos: de um lado, a consideração do PT como um partido socialdemocrata, portanto, sem nenhum compromisso com a causa dos comunistas (tema que valeria ser mais bem explorado em outro texto, mas que não é nosso objetivo aqui); de outro, a percepção da formação de uma esquerda antipetista, que para além 
dos rancores de alguns dos seus dirigentes pela militância pregressa no próprio PT (que podem ser minimizados em contextos não eleitorais, mas não desprezados), descambou para os desvios de esquerda, ou o esquerdismo.

Alguém um dia criou a alcunha "viúvas do PT". Independentemente daquele contexto, poderíamos pensar hoje que existe gente sofrendo de viuvez ou dos dramas do adultério: a viuvez faz lamentar aquele que não voltará jamais; o traído vive a mistura da saudade e do rancor raivoso por aquele que um dia acreditou ser o companheiro ideal para seguir até o final dessa jornada. Caso caiba aqui um dado da experiência pessoal, lembro bem no começo da década de 1990 como muitos dos que hoje engrossam as fileiras das organizações esquerdistas e de partidos de direita declaravam a certeza e o amor à alternativa popular e (na cabeça deles) revolucionária que significava o PT.

Viuvez ou adultério, pouco importa. O fato mesmo é que o campo do esquerdismo é composto por partidos que saíram de dentro do PT (PSOL, PSTU e PCO) ou que recebeu militantes oriundos do PT (como o caso do PCB) ali na metade do primeiro mandato de Lula, que passaram a cumprir importantes papéis de direção e participaram de mudanças qualitativas na linha política e na organização. As referidas organizações possuem o mérito de manterem, afirmativamente, a bandeira do socialismo e a compreensão da necessidade do processo revolucionário vivos, mas que (e por razões diversas) não conseguindo participar das lutas concretas e das contradições realmente existentes em nossa conjuntura, atuam negativamente com relação à própria possibilidade de avanço desse processo, embora ressalvas devam ser feitas a setores do PSOL e ao PCO, que têm feito algum esforço em participar, a seu modo, da vida concreta. Além de PCB, PCO, PSOL e PSTU, há mais uma porção de "coletivos", "agrupamentos", "ligas" e outras coisas que possuem, cada qual a sua maneira e de forma cada vez mais isolada, um belo discurso revolucionário e "vanguardeiro". Quanto menores e mais distantes da realidade, mais esses pequenos grupos se apresentam como os portadores da verdade revolucionária.

Confundindo a realidade objetiva com a própria vontade (como é próprio do esquerdismo) esses grupos confundem o objetivo revolucionário (estratégico) com as mediações necessárias e cambiantes de cada conjuntura (a tática): ao afirmar a necessidade da revolução, afirmam também que as condições para que ela ocorra já estão presentes, atribuindo aos traidores da classe (como é próprio do trotskismo) ou a pequenos ajustes conjunturais a razão do seu atraso. Não é raro dirigentes dessas organizações verem "o proletariado revolucionário" em ação nas ruas, mesmo quando temos apenas uma 
manifestação massiva e plena de contradições com tendências majoritárias à direita, como foram as tais "jornadas de junho" de 2013.

Essas organizações, no conjunto, representam a outra face ou possibilidade da manifestação política da pequena-burguesia: o revolucionarismo pequeno-burguês. Mesmo que tenham participado daqueles eventos de 2013, por exemplo, a reboque de agrupamentos da direita e a duras penas com seu reduzido número de militantes, essas organizações e militantes tendem a ver-se como a essência cristalina e pura da transformação revolucionária como mero ato subjetivo da vontade. Não conseguiram explicar até hoje como o "proletariado revolucionário" das ruas de junho apareceu depois, nas urnas, como eleitor de Aécio Neves e de Marina Silva e, depois, como a base social que pediu o impeachment de Dilma e até a ditadura militar. Insistem apenas em proclamar-se os fiéis representantes da "rebeldia das ruas", ainda que ela não tenha ocorrido em canto algum ou ainda que a "rebeldia" seja politicamente de direita. O inimigo comum - o ciclo de governos petistas - fez com que a pequena burguesia se unificasse nas suas manifestações políticas mais extremadas: o revolucionarismo esquerdista e o fascismo, o primeiro a reboque do segundo. A letargia dessas organizações esquerdistas com relação à escalada de direita e seu apoio prático ao golpe são os sintomas da sua ausência de realidade, de sua incapacidade de análise concreta da situação concreta, de posições moralistas (o famoso "isso é culpa do próprio PT...") e de um ranço que apenas pode ser compreendido como subjetivo e que cega a todos ou parte de seus dirigentes.

Há dois argumentos rápidos que devem ser apresentados para exemplificar os argumentos contrários ao esquerdismo. Um deles é socioeconômico, mais óbvio e já mencionado mais acima; outro é somente político.

No primeiro caso, retomemos o argumento de que o governo de Dilma e os governos do PT tiveram problemas que precisam ser bem criticados. O partido ajustou-se perfeitamente à lógica do jogo capitalista, assim como todo e qualquer governo anterior, assim como todas as instâncias pelo país afora, assim como quase todos os partidos. Mas foram governos que jamais pretenderam ou prometeram fazer além do que fizeram: gerenciar o capitalismo brasileiro concedendo ou reconhecendo alguns direitos a mais aos trabalhadores e às populações mais empobrecidas. Nisso todos os que são do campo da esquerda estão plenamente de acordo. O problema é que isso não é pouco e, muito menos, desprezível. Aí está o problema! Um documento do PCB, por exemplo, que defendia o voto nulo no segundo turno da eleição presidencial de 2014, afirmava que Aécio e Dilma eram iguais: Dilma era capitalismo com mais Estado, Aécio com menos. Burrice: o que chamaram de maneira 
imprecisa de "mais ou menos Estado", nas nossas condições objetivas, significou retirar ou lançar muita gente na miséria absoluta e isso deveria interessar bastante aos que lutam ao lado dos trabalhadores.

Constatar que os governos de Lula e Dilma serviram ao grande capital é como afirmar com tom de descoberta científica que fogo queima e água molha. Não apenas o de Dilma e Lula, mas também os de FHC, de Collor, de Sarney, os dos generais da ditadura. Para marxistas deveria ser bem óbvio que, dentro da ordem burguesa, não apenas o Estado, mas toda a estrutura jurídico-política serve ao grande capital. O mesmo vale para o tratamento dos limites dos processos eleitorais dentro dessa ordem. O que falta aqui é perceber, a partir da análise da nossa conjuntura e não da que a vontade desejava que existisse, que a ordem burguesa, assim como o processo revolucionário, não são estáticos, portanto, são plenos de movimento e de contradições. É tendo como referência o objetivo estratégico que as mediações com a vida real precisam ser construídas. Isso significa participar da vida e das lutas do cotidiano dos trabalhadores, das condições severas e adversas que abrem as possibilidades de avançar um passo aqui e recuar outros ali. Significa atuar em todas as contradições possíveis dentro da ordem burguesa, no sentido de aguçá-las ou, no mínimo, de torná-las de alguma maneira movimentos com resultados favoráveis aos trabalhadores.

Não podemos afirmar que os governos Lula e Dilma foram iguais aos governos de FHC. O esquerdismo é leviano e irresponsável quando diz isso. Há, sem dúvida, uma melhora nas condições de vida dos trabalhadores, em particular dos mais empobrecidos, mudanças que, aliás, têm mudado o cenário de alguns cantões do Brasil, utilizados até pouco tempo como reserva de votos de legendas da direita, como o DEM. Ocorreram mudanças, mudanças qualitativas, que abriram novas contradições, tanto entre frações do capital (como vimos), como para a atuação dos setores mais avançados da esquerda, com possível acesso a áreas e a contingentes de trabalhadores que, tendo necessidades básicas sanadas, se abrem também para a possibilidade de outras soluções. Apenas com forte trabalho e a partir dessas novas possibilidades há construção efetiva de organizações revolucionárias e a possibilidade, no longo prazo, da retomada concreta da perspectiva socialista.

Mas se não bastassem essas novas e as antigas possibilidades que se abriam para que a tomada de posição em defesa desses governos e contra golpe ocorresse, pelo menos seria razoável considerar a situação daqueles que estão mais fragilizados pela pobreza extrema. Embora sejamos ainda um país de pobres, esse período recente conseguiu retirar da fome milhões de pessoas. Isso somente é um dado secundário para a pequena burguesia (de direita 
e de esquerda). A preservação de programas sociais e a luta popular para que avançassem deveria ser uma bandeira das organizações mais avançadas.

Isso nos remete ao segundo argumento, que esclarece o esquerdismo e o antipetismo de esquerda, que serviu de base ao golpe. Há confusão entre elementos teóricos que utilizamos para pensar o modo de produção capitalista e a conjuntura política, que é cambiante. Exemplo para ir ao cerne da questão: o Estado, segundo Marx e Lênin, é sempre um Estado de classe. De alguma forma, a existência do Estado sempre será a ditadura de uma classe sobre outras, o "comitê executivo" da dominação de classe. Isso vale também para as formações sociais capitalistas. Mas essa que é uma ditadura de classe pode ser velada pela forma da democracia burguesa em períodos mais ou menos longos, sem perder, obviamente, suas características essenciais. O elemento fundamental que faz com que essa ditadura de classe seja obrigada a conviver com maiores ou menores liberdades democráticas é a luta de classes. Objetivamente, é a capacidade de organização política dos trabalhadores que força, alterando a correlação política de forças, conquistas sociais e também espaço de ação política. Somente os tolos podem acreditar que as condições de uma ditadura escancarada podem ser mais favoráveis à organização dos trabalhadores que as possibilidades de ação "abertas" pela democracia burguesa.

Era com a compreensão desse cenário que deveriam atuar com todas as forças contra o golpe todas as organizações dos trabalhadores. Isso não fez e não faria ninguém virar petista (ou retornar ao PT) e nem se tornar "governista": seria apenas atuar na nossa conjuntura politicamente e não de forma moralista, tendo clareza da nossa realidade concreta, atuando e aguçando suas contradições.

Engrossar o cordão da direita fazendo oposição pela esquerda é sempre um suicídio político. $\mathrm{O}$ antipetismo de direita e de esquerda fala línguas diferentes, mas fala e falou a mesma coisa: a deposição da presidenta representou um grande retrocesso para os trabalhadores brasileiros e é apenas um esforço bastante estúpido e infantil tratar disso analisando "culpas", ou afirmando que esse problema não é dos revolucionários.

Claro que essas organizações (novamente com a parcial exceção do PSOL) não possuem força política que poderia ser decisiva para impedir o golpe, o que não diminui sua responsabilidade como organização política. Essa fraqueza orgânica apenas revela que o esquerdismo não consegue adesão fora dos círculos pequeno-burgueses. Essas organizações são compostas majoritariamente por professores, estudantes e funcionários púbicos. Repensar a tática, atuar na conjuntura concreta, sem a postura moralista e infantil que tem marcado 
suas resoluções, é o único caminho e possibilidade de terem alguma relevância política. Os partidos trotskistas jamais compreenderão isso.

Mas o esquerdismo é implacável. A ausência de estrutura material e o desigual acesso aos meios de comunicação de massa justificam parcialmente a parca votação das candidaturas das organizações esquerdistas nas eleições e sua baixa inserção nos movimentos populares. Mas devemos também considerar suas dificuldades em dialogar com os trabalhadores e de participar dos problemas e das lutas cotidianas. Ao apresentar apenas o horizonte estratégico (socialista), sem as devidas mediações, essas organizações acabaram por se fechar ainda mais no universo pequeno-burguês, cujo radicalismo combina bem com sua linha política escatológica. Orgulham-se de não fazer política porque assumem o dever (moralista) de não lidar com nada que não seja diretamente a revolução. Como ela não chega logo, da mesma maneira que para os cristãos Jesus demora em voltar, vivem de apontar os dedos para os que se maculam nas fétidas águas da realidade objetiva. E tocam a vida satisfeitos e plenos de razão.

Portam-se como quem chega virgem aos cem anos e nada mais lhe resta a não ser autovalorizar a própria pureza, ainda que ninguém se importe com isso.

\section{Considerações finais}

Para poder concluir, é necessário reafirmar que o governo de Dilma Rousseff foi derrubado por seus méritos, não por outro motivo. É necessário ir para além das facilidades da análise para compreender sua real dimensão e sentido. É ser rasteiro e leviano tanto afirmar que era um serviçal governo de direita que perdeu a importância e foi descartado, como fazem os esquerdistas, quanto alegar que os governos do PT são os mais corruptos da história e que quebraram o Brasil, como faz o antipetismo de direita.

Foi um golpe dado contra a nossa frágil democracia, que favorece a organização e ação popular, um golpe dado contra as conquistas sociais, um golpe dado contra os avanços da luta contra o racismo, um golpe dado contra os avanços do movimento feminista, um golpe dado na luta contra a homofobia. Fundamentalmente, um golpe violento contra os cantões do Brasil, um golpe que vai interromper mudanças fundamentais que trouxeram condições mínimas de dignidade para uma parcela considerável da população brasileira. Um golpe que pretende recriar no Brasil as condições para a acentuação da exploração dos 
trabalhadores e das nossas riquezas pelo grande capital estrangeiro, com a retomada do projeto neoliberal e como as reformas propostas têm demonstrado.

Por enquanto, vale a constatação de que os neomilitantes da direita e os do esquerdismo preferem facilidades: análises de lógica formal, sem contradições. Um programa redondinho e internamente coerente, ainda que não tenha relação com a realidade.

Valeria aos que histericamente pediram o impeachment de Dilma ou aos que desdenharam do golpe pensar um pouco nos pressupostos do que chamam de "limpeza" da política ou de "nova" política e nas soluções para nossos problemas mais graves. Caso sejam capazes de fazer isso, descobrirão que as soluções que andam apoiando representam um passo atrás muito perigoso. Que as marionetes pequeno-burguesas desse jogo antipopular que estão dispostas em extremos à esquerda e à direita percebam que há tempos deram os braços e ajudam a abrir as portas do próprio abismo.

\section{Referências Bibliográficas}

BOITO, Armando. "A crise política do neodesenvolvimentismo e a instabilidade da democracia”. Revista Crítica Marxista. Campinas, n42, jun., 2016.

. “A corrupção como ideologia”. Revista Crítica Marxista. Campinas, n44, jun., 2017.

LÊNIN, Vladimir Ilitch Ulianov. "A doença infantil do 'esquerdismo' no comunismo".

LÊNIN, Vladimir Ilitch Ulianov. Obras escolhidas - volume 3. São Paulo: Alfa-Ômega, 1980. p. 275-349.

MORAES, João Quartim de. Base de massas e tropas de choque do golpismo. Disponível em: http://www.vermelho.org.br/coluna.php?id_coluna texto=7690\&id_coluna $=24$. Acesso: 25 de maio de 2017.

POULANTZAS, Nicos. Pouvoir politique et classes sociales. Paris: François Maspero, 1968. Fascismo e ditadura. Porto: Portucalense, 1972, 02 volumes. 